\title{
Changes in Cutting Composition during Early Stages of Adventitious Rooting of Miniature Rose Altered by Inoculation with Arbuscular Mycorrhizal Fungi
}

\author{
C.F. Scagel \\ U.S. Department of Agriculture, Agricultural Research Service, Horticultural Crops Research Unit, \\ 3420 NW Orchard Avenue, Corvallis, OR 97330
}

\begin{abstract}
Additional Index words. Rosa spp. 'Scarlet Cupido', 'Sunrise Cupido', 'Blue Cupido', 'Favorite Cupido', Glomus intraradices, arbuscular mycorrhizae
\end{abstract}

\begin{abstract}
Many changes in metabolism are known to occur during adventitious root formation, including changes in amino acids, proteins, and carbohydrates. The influence of arbuscular mycorrhizal fungi (AMF) on adventitious rooting of rose was tested by inoculating four cultivars with Glomus intraradices Schenck \& Smith. Changes in cutting composition were measured during the initial stages of adventitious root formation. Although there were cultivarspecific differences in response, AMF inoculation generally increased the biomass and number of adventitious roots on cuttings before root colonization was detected. Application of rooting hormone increased this effect. Inoculation with AMF washings also increased the root biomass and number, but only when cuttings were treated with hormone. Changes in cutting composition in response to AMF were detected at 7 to 14 days. Differences in protein concentrations in response to AMF or hormone application were similar, while differences in amino acid and reducing sugar concentrations were not. Concentrations of proteins and amino acids in cuttings at the beginning of the experiment were positively correlated with adventitious rooting, while concentrations of reducing sugars and nonreducing sugars were not correlated with rooting. These results suggests that nitrogen-containing compounds play an important role in adventitious rooting, and that changes in amino acids associated with AMF inoculation were potentially different than those that occurred when cuttings were treated with rooting hormone alone. Carbohydrate concentrations in cuttings were not strongly related to initiation of adventitious roots, but reducing sugar may play a role in regulating part of the response of cuttings to AMF. The response of rose cuttings prior to colonization by $G$. intraradices suggests that AMF-plant signaling events occurred prior to rooting.
\end{abstract}

Arbuscular mycorrhizal fungi (AMF) commonly form beneficial associations with roots of many horticultural crops (Smith and Read, 1997). However, methods that facilitate optimal use of commercially available AMF inoculum, such as timely application, have not been well defined. For example, AMF benefits to plant growth appear to be highest when colonization occurs during early stages of plant growth (Chang, 1994; Nemec, 1987). Therefore, to obtain these benefits in horticultural production systems, inoculum should be present during radicle emergence after seed germination and adventitious root formation in cutting propagation, or prior to the acclimation phase of tissue culture production.

Miniature roses (Rosa L.) are commonly propagated by cuttings and, like most commercial cultivars, are relatively easy to root. Successful adventitious rooting during cutting propagation depends on several factors, including the physiological condition of the propagation stock plants and the environmental conditions during adventitious root formation (Hartmann et al., 1997). In previous work, Scagel (2001) found that adding AMF inoculum to rooting medium increased root initiation and growth on cuttings of miniature rose. However, inoculum responses were not always

Received for publication 21 Oct. 2003. Accepted for publication 31 Mar. 2004. The gratefully acknowledges the technical assistance of Kathy Eggemeyer, Ben Jackson, Lisa Tribbet, Jesse Mitchell, and Fred Senecal, editorial assistance of Maryann Resendes and R. Paul Schreiner, and donation of plant material from Yoder Brothers, Inc. Barberton, Ohio. Mention of trademark, proprietary product, or vendor does not constitute a guarantee or warranty of the product by the U.S. Dept. of Agriculture and does not imply its approval to the exclusion of other products or vendors that also may be suitable. associated with increased levels of root colonization by AMF.

Douds et al. (1995) found that AMF influence plant growth and adventitious root development prior to colonization in Sciadopitys verticillata (Thunberg) Siebold \& Zucc. cuttings. This ability to alter root formation prior to colonization suggests that signaling occurs between the fungus and the cutting, which alters the metabolism of cuttings. Early changes in root initiation and growth resulting from AMF inoculation may be either due to the presence of fungus in the inoculum, or the coincidental inoculation with bacteria associated with AMF inoculum.

The objectives of this study were to determine 1) whether physical, chemical, or biological components of AMF inoculum induce changes in adventitious rooting of miniature rose, and 2) the time frame in which these changes in rooting occur.

\section{Materials and Methods}

STOCK PLANT CULTURE. Four cultivars of miniature rose were used in this study: 'Scarlet Cupido' (RUIskjol. PP\#12672), 'Sunrise Cupido' (RUIrosora, PP\#10685), 'Blue Cupido' (RUIbleu, PP\#9735), and 'Favorite Cupido' (RUIdodo, PP\#9633). Cultivars were obtained as cuttings from Yoder Brothers (Barberton, Ohio), and were rooted in 50- $\mathrm{mm}^{3}$-cell flats (126 cells per flat) of wedgeshaped Oasis Growing Medium (\#5615; Smithers-Oasis Co., Cuyahoga Falls, Ohio) under intermittent mist. Each rooted cutting was then transplanted into 0.64-L pots $(10.1 \mathrm{~cm}$ Gage Dura Pot \#GDP400; Gage Industries, Lake Oswego, Ore.) containing a mix of $80 \%$ peat (Sunshine Grower Grade White; SunGro Industries, Hubbard, Ore.) and 20\% perlite (Coarse Horticultural Grade; 
Supreme Perlite Co., Portland, Ore.) amended with $20 \mathrm{~mL} /$ pot of slow-release fertilizer [Osmocote 14N-6.1P-11.6K; Scotts Co., Marysville, Ohio (1.16 g nitrate-N, $1.64 \mathrm{~g}$ ammonical N, $2.2 \mathrm{~g} \mathrm{P}, 2.3 \mathrm{~g} \mathrm{~K})$ ]. Plants were maintained in a glasshouse under intermittent mist with supplemental light (16 h light/8 h dark) provided by high-pressure multi-vapor lamps with an average of $700 \mu \mathrm{mol} \cdot \mathrm{m}^{-2} \cdot \mathrm{s}^{-1}$ at canopy level. Average day/night temperatures were $21 / 16^{\circ} \mathrm{C}$. Plants were fertilized each week with $50 \mathrm{~mL}$ of liquid fertilizer $\left(\approx 94 \mathrm{mg} \cdot \mathrm{L}^{-1} \mathrm{~K}, 129 \mathrm{mg} \cdot \mathrm{L}^{-1} \mathrm{~N}, 12 \mathrm{mg} \cdot \mathrm{L}^{-1} \mathrm{P}, 26\right.$ $\mathrm{mg} \cdot \mathrm{L}^{-1} \mathrm{~S}, 40 \mathrm{mg} \cdot \mathrm{L}^{-1} \mathrm{Ca}, 38 \mathrm{mg} \cdot \mathrm{L}^{-1} \mathrm{Mg}$, and $<0.05 \%$ of $\mathrm{Mn}, \mathrm{Cu}$, $\mathrm{Zn}, \mathrm{B}$, and Mo), and watered as needed. After 6 weeks, plants were transplanted into cylindrical 3.8 -L pots $(19.4 \times 18.1 \mathrm{~cm}$; Lerio Corp., Mobile, Ala.) containing a mix of $30 \%$ composted Douglas-fir bark (Whitney Farms, Independence, Ore.), $60 \%$ peat, and $10 \%$ perlite amended with $50 \mathrm{~mL}$ of slow-release fertilizer per pot. Flower heads were pruned from plants weekly. Pests and pathogens were controlled as needed using the following: foliar application of $10 \%$ sodium bicarbonate solution, DMI fungicides and Benzimidazole for powdery mildew [Sphaerotheca pannosa (Wallr.:Fr.) Lév. var. rosae], imidacloprid for aphids, diflubenzuron for fungus gnats (Bradysia spp.), Neoseiulus fallacis Garman predators for spider mites (Tetranychus spp.), and N. cucumeris Oudemans predators for thrips (Frankiniella spp.).

MYCORRHIZAL INOCULUM. Glomus intraradices was originally obtained from Native Plants Inc. (Salt Lake City, Utah) and maintained in pot cultures at the USDA-ARS, Horticultural Crops Research Laboratory, Corvallis, Ore. The fungus was propagated in pot cultures on roots of bunching onion (Allium cepa $\mathrm{L}$. 'White Lisbon') grown in 1 loam : 1 sand for 5 months. The inoculum was a mixture of soil medium, extraradicle hyphae, spores, and colonized root segments ( $<2 \mathrm{~mm}$ in length). Infective propagules in the inoculum were estimated using the most probable number method (Woomer, 1994), and were on average 10 propagules/g of soil medium.

EXPERIMENTAL DESIGN. The experiment was a $4 \times 2$ factorial design with four inoculation treatments and two hormone treatments arranged in a randomized block design. Each treatment unit (pot) contained three cuttings (one for each harvest date) replicated two times in each of three blocks (six cuttings per treatment per harvest date). Within-block treatment replication was done to provide adequate replication for analysis of survival data.

Experiments on each cultivar were staggered $14 \mathrm{~d}$ apart. Three-node cuttings of each cultivar were taken 12-20 weeks after stock plants had been transplanted into pots. Cuttings were sorted for uniformity (based on fresh weight), sanitized by dipping the end of each cutting into $10 \%$ solution of sodium hypochlorite (Dixichlor; DXI Industries, Houston) for $20 \mathrm{~min}$, and rinsed with water. The distal node (containing stem tissue and one compound leaf) of each cutting was removed, immediately frozen in liquid nitrogen, and transferred to a $-20{ }^{\circ} \mathrm{C}$ freezer for later analyses. The remaining two-node cuttings were randomly placed into the eight treatment groups. After the appropriate hormone treatment was applied, cuttings were stuck directly into $10-\mathrm{cm}$ pots (Gage Dura Pot \#GDP400) containing $80 \%$ perlite, $20 \%$ peat, and the assigned inoculation treatment. Three cuttings were stuck per pot, and each pot treatment was replicated six times. Pots were randomized among flats and maintained under the same light and temperature conditions as the stock plants.

Cuttings in each inoculation treatment were either treated or untreated with rooting hormone prior to sticking. For the hormone treatment, cuttings were dipped for $2 \mathrm{~min}$ in a 1:10 dilution of Woods Hormone Solution (Earth Science Products Corp., Wil- sonville, Ore.) and distilled water. The solution was a commercial mixture of $1.03 \%$ indol-3-butyric acid and $0.66 \%$ 1-naphthalene acetic acid. For the nonhormone control treatment, cuttings were dipped in distilled water for $2 \mathrm{~min}$.

Inoculation treatments included: AMF inoculum, sterilized AMF inoculum, washings of AMF inoculum, and a noninoculated control. For AMF inoculation, $3 \mathrm{~mL}$ of nonsterilized inoculum was placed in the cuttings' rooting region prior to sticking. The sterilized treatment had $3 \mathrm{~mL}$ of sterilized inoculum incorporated into the rooting medium; this treatment was used to determine whether physical or chemical attributes of inoculum influenced rooting. In the inoculum washings treatment, sterilized inoculum was also added to the rooting medium as described for the sterilized treatment. In addition, $50 \mathrm{~mL}$ of washings from nonsterilized inoculum, which had been passed through a $28-\mu \mathrm{m}$ sieve (Tyler equivalent 400-mesh) and Whatman 1 filter paper, was applied to pots after the cuttings were stuck. This treatment was used to determine if microflora present in the inoculum influenced rooting. The control treatment received no inoculum or washings.

Measurements. One cutting from each pot was harvested 2, 7 , and $14 \mathrm{~d}$ after sticking for a total of six cuttings per treatment per harvest date. At each harvest, the condition of the cutting was rated as rooted, callused, or dead. The number of primary and secondary lateral roots on each cutting was counted, removed, and weighed. Stems (stem tissue and leaves) were also weighed. Subsamples ( $\approx 100-500 \mathrm{mg}$ ) of root tissue and the distal portion of the stem were frozen in liquid nitrogen and stored at $-20{ }^{\circ} \mathrm{C}$ for later analyses. A portion of fresh roots were cleared and stained using a modified procedure of Phillips and Hayman (1970) in which lacto-phenol was replaced with lacto-glycerin, and assessed for AMF colonization. AMF colonization was measured on $\approx 1$ $\mathrm{cm}$ sections of root samples using the Biermann and Linderman (1980) method. Remaining root and stem samples were dried at $60{ }^{\circ} \mathrm{C}$ and weighed.

Stem tissue collected at the beginning of the experiment and root and stem samples for each harvest were analyzed for total protein, amino acid, and sugar concentrations. Total soluble protein was determined colorimetrically using BIO-RAD (Coomassie Brilliant blue) (Bradford, 1976) after extraction of ground tissue (<50 mesh) in buffer (20 mm TRIS, $10 \mathrm{~mm} \mathrm{NaCl}, 10 \mathrm{~mm} \mathrm{KCl}, 2$ $\mathrm{mm} \mathrm{MgCl}_{2} \cdot 6 \mathrm{H}_{2} \mathrm{O}$ ) with Nonidet P-40. Total amino acid content of the samples was determined colorimetrically with ninhydrin (Yemm and Cocking, 1955). Total reducing and nonreducing sugar content of samples were determined colorimetrically using a modification of the Somolgyi-Nelson Alkaline Copper method (Dische, 1962; Nelson, 1944). Supernatant from ground tissue ( $<50$ mesh) was extracted with warm $80 \%$ ethanol to determine total reducing sugar content. The residual pellet from extraction was hydrolyzed in $0.2 \mathrm{~N} \mathrm{KOH}$ prior to analyses for nonreducing sugars.

Statistical anAlyses. Data for each cultivar were subjected to analysis of variance (ANOVA) with inoculation treatments, hormone treatments, and time as main effects. Dry weight and root number data were square-root transformed prior to analysis to correct for unequal variance and to achieve a best-model fit; nontransformed data are reported in tables and figures. Orthogonal contrasts were used to address specific questions within cultivars (e.g., response to noninoculated vs. AMF-inoculated treatments over time). Where appropriate, the Bonferroni test was used to separate treatment means at $P<0.05$. Means of variables that exhibit unequal variance between treatments that could not be equalized by transformation were separated using the Kolmogo- 
rov-Smirnov two-sample test. Where nonparametric procedures were used to separate means, annotation is provided in the tables and figures. In all instances, responses of control cuttings were not statistically different than cuttings treated with sterilized inoculum. To simplify data presentation, data from the sterilized inoculum treatment are not presented. For many variables, cultivars responded similarly to treatments; only the magnitude of the response varied between cultivars. Therefore, data is presented for only one representative cultivar (annotation is provided in the figures). Relationships between variables across cultivars were assessed using Spearman rank order correlation (Spearman R) (Gibbons, 1985). All data analyses were performed using the Statistica statistical package (Statsoft, Tulsa, Okla.).

\section{Results}

STEM TISSUE. Stem moisture content increased (decrease in dry: fresh weight ratio) in cuttings of miniature rose cultivars $2 \mathrm{~d}$ after sticking (Fig. 1A), and then decreased. Moisture content in both hormone and AMF treatments changed less during the experiment than cuttings that received neither hormone nor inoculum [e.g., results from orthogonal contrasts for 'Scarlet Cupido' (Fig. 1B-C)]. In hormone treatments, different cultivars showed similar trends in tissue hydration over time; cultivars differed only in the magnitude of response to hormone application (data not shown). Increased tissue hydration at the end of the experiment coincided with visible root formation, and was probably due to an increase in the cutting's ability to take up water. However, during the first few days after sticking, inoculated cuttings were less hydrated than noninoculated cuttings (e.g., 'Scarlet Cupido', Fig. 1C), which may be due to decreased amount of callus on inoculated cuttings (data not shown).

Changes in stem protein concentrations and total protein contents of the cuttings after sticking varied among cultivars (Fig. 2A-B) and increased when hormone was applied (e.g., 'Sunrise Cupido' Fig. 2C-D). At 14 d, AMF inoculated cuttings had higher concentrations of proteins in their stems and higher total protein content than cuttings inoculated with AMF washings or noninoculated cuttings (e.g., 'Sunrise Cupido', Fig. 2E-F). Changes in protein concentration and content that occurred during the $14 \mathrm{~d}$ of the experiment were similar in control cuttings and cuttings that received washings from inoculum (e.g., results from orthogonal contrasts for 'Sunrise Cupido', Fig. 2F)

Amino acid concentrations and total amino acid contents also varied among cultivars (Fig. 3A, B). Amino acid responses to AMF and hormone treatments differed from the protein responses (Fig. 3). At 2 d, cuttings with hormone had lower concentrations of amino acids in their stems and lower total amino acid content than nonhormone treatments. However, at $14 \mathrm{~d}$, hormone treated cuttings had higher concentrations and contents of amino acids

\footnotetext{
Fig. 1. Change in moisture content of stems of four miniature rose cultivars (A) during the first $14 \mathrm{~d}$ after sticking in response to hormone $(\mathbf{B})$ and inoculation treatments $(\mathbf{C})$. Cultivars: BC = 'Blue Cupido', FC = 'Favorite Cupido', $\mathrm{SC}=$ Scarlet Cupido, and SU = 'Sunrise Cupido'. Hormone treatments: N = no hormone, $\mathrm{H}=$ hormone . Inoculation treatments: $\mathrm{C}=$ no inoculum, $\mathrm{W}$ = washings from arbuscular mycorrhizal fungus (AMF) inoculum, and $\mathrm{A}=$ $\mathrm{AMF}$ inoculum. Columns represent means and error bars in represent the SE of treatment means. Columns with the same letter above them within a cultivar (A) are not significantly different from each other $(P<0.05$, Bonferroni test). Columns with the same lowercase letter above them across all treatments (B, C) are not significantly different from each other $(P<0.05$, Bonferroni test $)$ Groups of columns with the same uppercase letter above them $(B, C)$ denote no significant difference in response over time (between treatment orthogonal contrast $P<0.05)$.
}
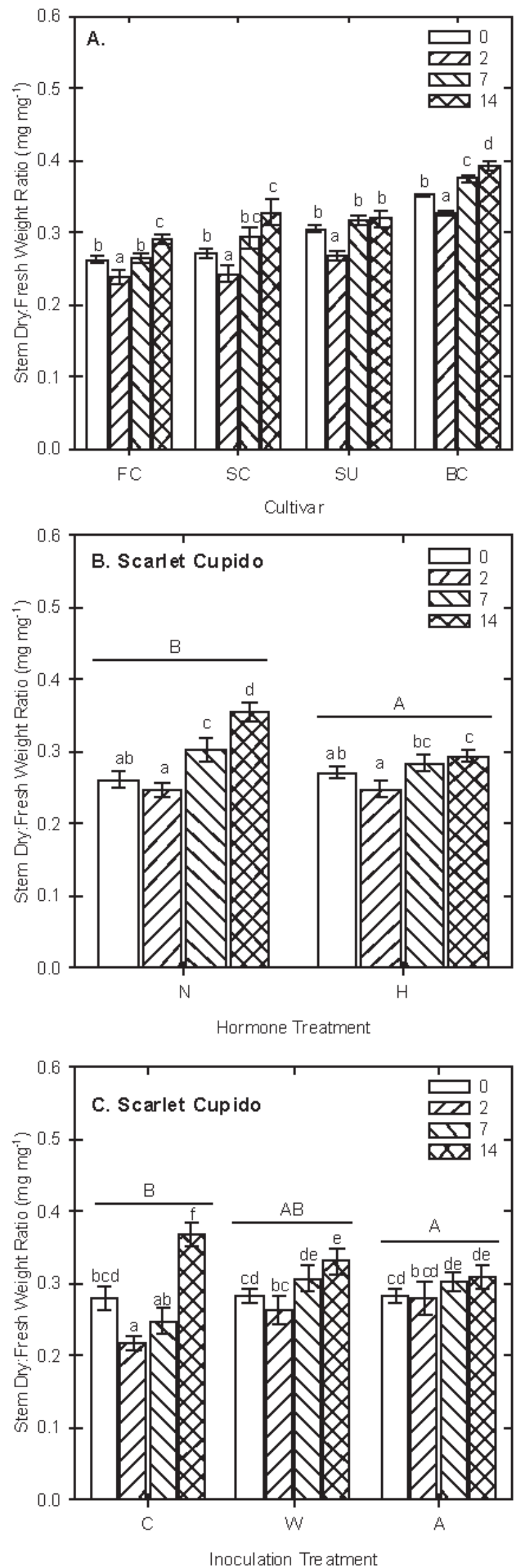

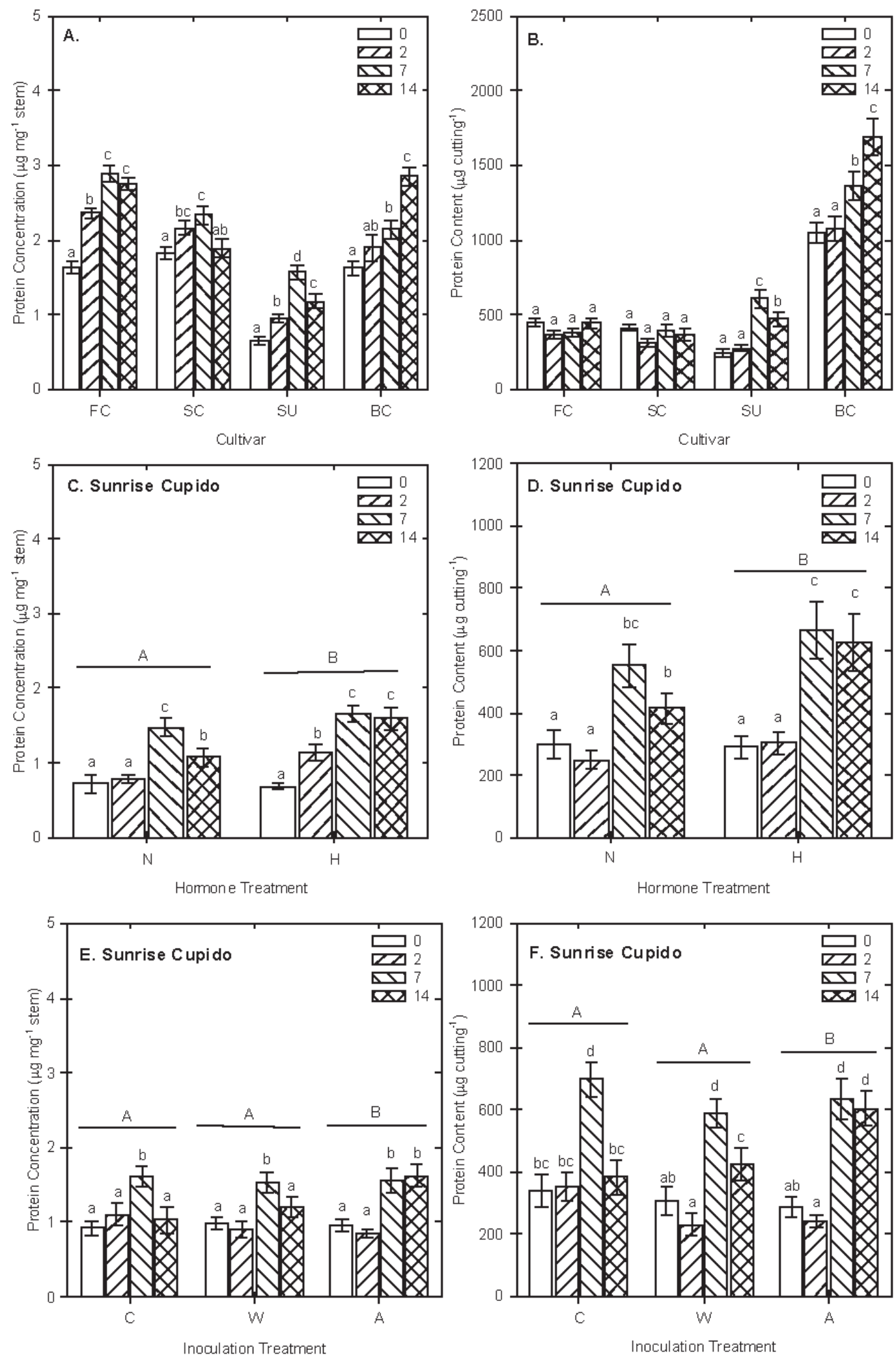

Fig. 2. Change in protein concentration of stems $(\mathbf{A}, \mathbf{C}, \mathbf{E})$ and content of cuttings $(\mathbf{B}, \mathbf{D}, \mathbf{F})$ of four miniature rose cultivars $(\mathbf{A}, \mathbf{B})$ during the first $14 \mathrm{~d}$ after sticking in response to hormone $(\mathbf{C}, \mathbf{D})$ and inoculation treatments $(\mathbf{E}, \mathbf{F})$. Cultivars: $\mathrm{BC}=$ 'Blue Cupido', $\mathrm{FC}=$ 'Favorite Cupido', $\mathrm{SC}=\mathrm{Scarlet} \mathrm{Cupido}$, and $\mathrm{SU}=$ 'Sunrise Cupido'. Hormone treatments: $\mathrm{N}=$ no hormone, $\mathrm{H}=$ hormone . Inoculation treatments: $\mathrm{C}=$ no inoculum, $\mathrm{W}=$ washings from arbuscular mycorrhizal fungus (AMF) inoculum, and $\mathrm{A}=\mathrm{AMF}$ inoculum. Columns represent means and error bars in represent the SE of treatment means. Columns with the same letter above them within a cultivar (A, B) are not significantly different from each other $(P<0.05$, Bonferroni test). Columns with the same lowercase letter above them across all treatments $(\mathrm{C}-\mathrm{F}$.) are not significantly different from each other $(P<0.05$, Bonferroni test). Groups of columns with the same uppercase letter above them (C-F) denote no significant difference in response over time (between treatment orthogonal contrast $P<0.05$ ). 

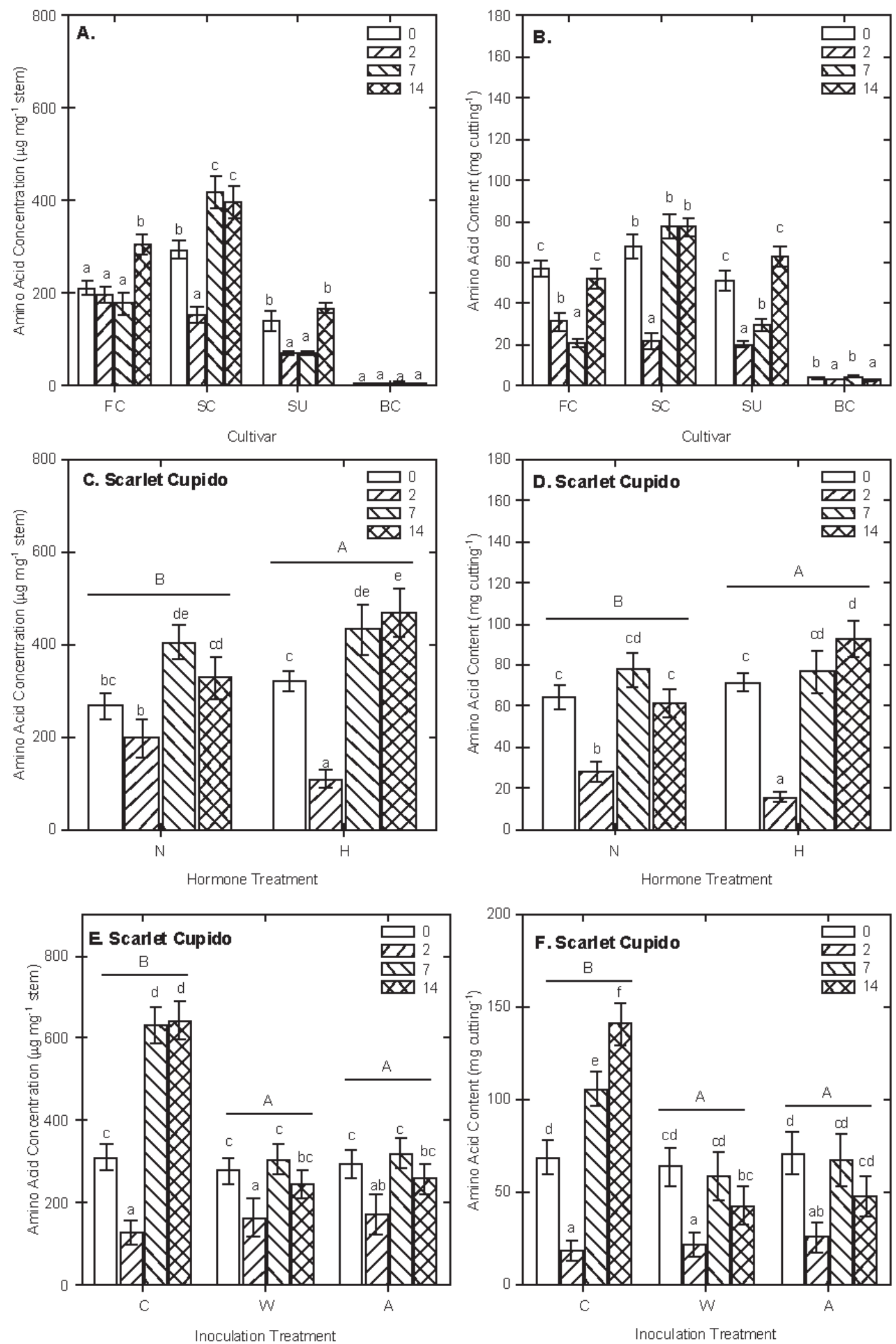

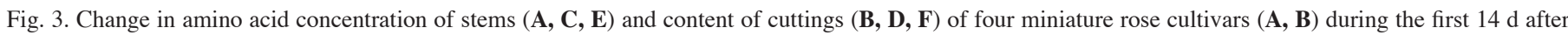
sticking in response to hormone $(\mathbf{C}, \mathbf{D})$ and inoculation treatments $(\mathbf{E}, \mathbf{F})$. Cultivars: BC $=$ 'Blue Cupido', FC $=$ 'Favorite Cupido', SC $=$ Scarlet Cupido, and SU = 'Sunrise Cupido'. Hormone treatments: $\mathrm{N}=$ no hormone, $\mathrm{H}=$ hormone . Inoculation treatments: $\mathrm{C}=$ no inoculum, $\mathrm{W}=$ washings from arbuscular mycorrhizal fungus (AMF) inoculum, and $\mathrm{A}=\mathrm{AMF}$ inoculum. Columns represent means and error bars in represent the sE of treatment means. Columns with the same letter

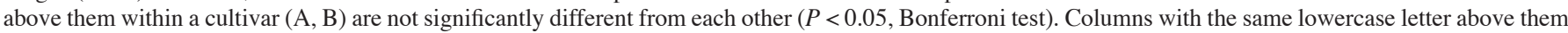
across all treatments $(\mathrm{C}-\mathrm{F})$ are not significantly different from each other $(P<0.05$, Bonferroni test). Groups of columns with the same uppercase letter above them $(\mathrm{C}-\mathrm{F})$ denote no significant difference in response over time (between treatment orthogonal contrast $P<0.05$ ). 

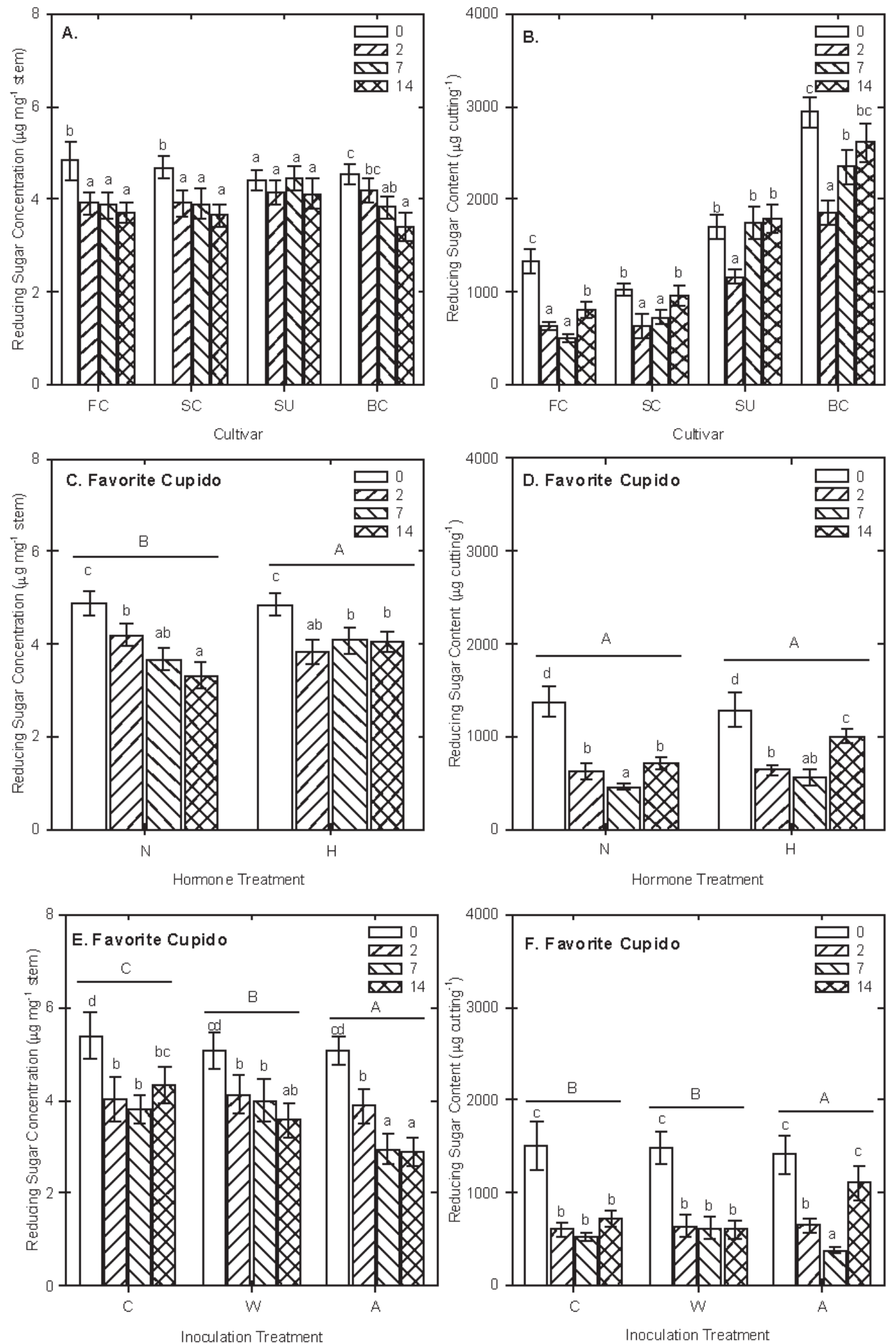

Fig. 4. Change in reducing sugar concentration of stems $(\mathbf{A}, \mathbf{C}, \mathbf{E})$ and content of cuttings $(\mathbf{B}, \mathbf{D}, \mathbf{F})$ of four miniature rose cultivars $(\mathbf{A}, \mathbf{B})$ during the first $14 \mathrm{~d}$ after sticking in response to hormone $(\mathbf{C}, \mathbf{D})$ and inoculation treatments $(\mathbf{E}, \mathbf{F})$. Cultivars: $\mathrm{BC}=$ 'Blue Cupido', FC $=$ 'Favorite Cupido', SC $=\mathrm{Scarlet}$ Cupido, and SU = 'Sunrise Cupido'. Hormone treatments: $\mathrm{N}=$ no hormone, $\mathrm{H}=$ hormone . Inoculation treatments: $\mathrm{C}=$ no inoculum, $\mathrm{W}=$ washings from arbuscular mycorrhizal fungus (AMF) inoculum, and $\mathrm{A}=\mathrm{AMF}$ inoculum. Columns represent means and error bars in represent the SE of treatment means. Columns with the same letter above them within a cultivar (A, B) are not significantly different from each other $(P<0.05$, Kolmogorov-Smirnov test). Columns with the same lowercase letter above them across all treatments (C-F.) are not significantly different from each other $(P<0.05$, Kolmogorov-Smirnov test). Groups of columns with the same uppercase letter above them $(\mathrm{C}-\mathrm{F})$ denote no significant difference in response over time (between treatment orthogonal contrast $P<0.05$ ). 
than nonhormone treated cuttings (e.g., 'Scarlet Cupido', Fig. 3C, D). Inoculation had no influence on the amino acid concentrations in stems or total amino acid content at $2 \mathrm{~d}$. However, at 7 and $14 \mathrm{~d}$, cuttings inoculated with AMF or AMF washings had much lower concentrations of amino acids in their stems and lower total amino acid content than noninoculated cuttings (e.g. 'Scarlet Cupido', Fig. 3E, F). Changes in protein concentration and content that occurred during the $14 \mathrm{~d}$ of the experiment were different in control cuttings than cuttings that received washings from inoculum or inoculum (e.g., results from orthogonal contrasts for 'Scarlet Cupido', Fig. 3F)

Changes in nonreducing sugars in response to hormone or AMF were highly dependant on cultivar and were not specifically related to rooting (data not shown). Reducing sugar concentrations showed little variation among cultivars. However, reducing sugar content varied among cultivars with 'Blue Cupido' showing the highest content (Fig. 4A-B). Reducing sugars concentrations and total content varied with hormone application and AMF inoculation. At $2 \mathrm{~d}$, hormone treated cuttings had lower concentrations of reducing sugars in their stems than nonhormone treated cuttings. However, at $14 \mathrm{~d}$, hormone treated cuttings had higher concentrations of reducing sugars than nonhormone treated cuttings (e.g. 'Favorite Cupido', Fig. 4C). Hormone treatments had no influence on total content of reducing sugars in cuttings at $7 \mathrm{~d}$, however, at $14 \mathrm{~d}$, hormone treated cuttings had a higher total content of reducing sugars than nonhormone treatment (e.g., 'Favorite Cupido', Fig. 4D). Changes in reducing sugar content that occurred during the 14 $\mathrm{d}$ of the experiment were similar in cuttings treated with hormones and nonhormone treated cuttings (e.g., results from orthogonal contrasts for 'Favorite Cupido', Fig. 4D). Inoculation had no influence on the reducing sugar concentrations in stems or total reducing sugar content of cuttings at $2 \mathrm{~d}$. By 7 and $14 \mathrm{~d}$, AMF treatments had lower concentrations of reducing sugars in their stems than noninoculated treatments (e.g., 'Favorite Cupido', Fig. $4 \mathrm{E})$ but higher total reducing sugar contents than noninoculated treatments at $14 \mathrm{~d}$ (e.g., 'Favorite Cupido', Fig. 4F). Changes in reducing sugar concentration that occurred during the $14 \mathrm{~d}$ of the experiment were different in control cuttings than cuttings that received washings from inoculum or inoculum (e.g., results from orthogonal contrasts for 'Favorite Cupido', Fig. 4D).

Adventitious Roots. Adventitious roots were produced on miniature rose cuttings by $14 \mathrm{~d}$ after sticking, but there were no detectable signs of root AMF colonization in cuttings treated with inoculum. AMF inoculum significantly increased root biomass and the number of adventitious roots produced on all cultivars, except for 'Blue Cupido', when hormone was applied (Table 1). AMF washings also increased root production in some cases when hormone was applied, but did not increase root production as consistently as AMF inoculation (Table 1).

Protein content of roots accounted for less than $10 \%$ of the total protein in cuttings, but cuttings inoculated with AMF or AMF washings had a higher proportion of total protein in roots than noninoculated treatments (Fig. 2 and Table 2). Similarly, hormone treatments had a higher proportion of total protein content in roots (8\% to $9 \%$ ) than nonhormone treatments $(3 \%)$. Amino acid content of roots accounted for less than $10 \%$ of the total amino acid content in cuttings (Fig. 3 and Table 2). However, AMF treatments had a higher proportion of total amino acid in roots $(\approx 10 \%)$ than cuttings from other inoculation treatments ( $2 \%$ to $3 \%$ ). Similarly, hormone treatments had a higher proportion of total amino acid content in roots $(\approx 8 \%)$ than nonhormones treatments $(\approx 3 \%)$.

Reducing sugar content of roots accounted for up to $37 \%$ of the total reducing sugar content in cuttings (Fig. 4 and Table 2). AMF treatments had a higher proportion of total reducing sugars in roots $(\approx 37 \%)$ than noninoculated cuttings $(\approx 11 \%)$ or cuttings

Table 1. Influence of hormone and inoculation treatments on root initiation and growth of cuttings from four miniature rose cultivars $14 \mathrm{~d}$ after sticking.

\begin{tabular}{|c|c|c|c|c|c|c|}
\hline \multirow[b]{2}{*}{ Variable } & \multirow{2}{*}{$\begin{array}{l}\text { Hormone } \\
\text { treatmenty }\end{array}$} & \multirow{2}{*}{$\begin{array}{l}\text { Inoculation } \\
\text { treatment }^{\mathrm{x}}\end{array}$} & \multicolumn{4}{|c|}{ Cultivarz $^{z}$} \\
\hline & & & FC & $\mathrm{SC}$ & SU & $\overline{\mathrm{BC}}$ \\
\hline \multirow{6}{*}{$\begin{array}{l}\text { Root dry weight } \\
\text { (mg/cutting) }\end{array}$} & $\mathrm{N}$ & $\mathrm{C}$ & $4.53 \mathrm{a}^{\mathrm{w}}$ & $2.59 \mathrm{a}$ & $0.51 \mathrm{a}$ & $0.12 \mathrm{a}$ \\
\hline & & $\mathrm{W}$ & $8.54 \mathrm{ab}$ & $6.42 \mathrm{ab}$ & $1.01 \mathrm{a}$ & $0.33 \mathrm{a}$ \\
\hline & & A & $13.73 \mathrm{~b}$ & $11.67 \mathrm{~cd}$ & $8.46 \mathrm{~b}$ & $0.34 \mathrm{a}$ \\
\hline & $\mathrm{H}$ & $\mathrm{C}$ & $13.79 \mathrm{~b}$ & $8.49 b c$ & $2.52 \mathrm{a}$ & $0.20 \mathrm{a}$ \\
\hline & & W & $25.83 \mathrm{c}$ & $14.62 \mathrm{de}$ & $4.23 \mathrm{ab}$ & $0.35 \mathrm{a}$ \\
\hline & & A & $41.91 \mathrm{~d}$ & $18.63 \mathrm{e}$ & $39.25 \mathrm{c}$ & $0.39 \mathrm{a}$ \\
\hline \multirow{6}{*}{$\begin{array}{l}\text { Roots } \\
\text { (no./cutting) }\end{array}$} & $\mathrm{N}$ & $\mathrm{C}$ & $1.33 \mathrm{a}$ & $1.00 \mathrm{a}$ & $1.00 \mathrm{a}$ & $0.51 \mathrm{a}$ \\
\hline & & W & $0.95 \mathrm{a}$ & $2.69 \mathrm{a}$ & $1.17 \mathrm{a}$ & $0.83 \mathrm{a}$ \\
\hline & & A & $1.00 \mathrm{a}$ & $2.83 \mathrm{a}$ & $2.50 \mathrm{a}$ & $1.50 \mathrm{a}$ \\
\hline & $\mathrm{H}$ & $\mathrm{C}$ & $2.33 \mathrm{~b}$ & $6.67 \mathrm{~b}$ & $10.83 \mathrm{~b}$ & $1.01 \mathrm{a}$ \\
\hline & & W & $6.52 \mathrm{c}$ & $9.02 \mathrm{c}$ & $13.83 \mathrm{~b}$ & $1.85 \mathrm{a}$ \\
\hline & & A & $6.67 \mathrm{c}$ & $9.50 \mathrm{c}$ & $18.17 \mathrm{c}$ & $1.67 \mathrm{a}$ \\
\hline \multirow{6}{*}{$\begin{array}{l}\text { Root size } \\
(\mathrm{mg} / \mathrm{root})\end{array}$} & $\mathrm{N}$ & $\mathrm{C}$ & $3.99 \mathrm{a}$ & $2.59 \mathrm{a}$ & $0.51 \mathrm{a}$ & $0.19 a$ \\
\hline & & W & $8.99 \mathrm{~b}$ & $2.62 \mathrm{a}$ & $0.84 \mathrm{a}$ & $0.35 \mathrm{a}$ \\
\hline & & A & $13.73 \mathrm{c}$ & $3.95 \mathrm{a}$ & $3.62 \mathrm{~b}$ & $0.27 \mathrm{a}$ \\
\hline & $\mathrm{H}$ & $\mathrm{C}$ & $9.18 \mathrm{~b}$ & $2.47 \mathrm{a}$ & $0.23 \mathrm{a}$ & $0.18 \mathrm{a}$ \\
\hline & & W & $8.46 \mathrm{~b}$ & $3.36 \mathrm{a}$ & $0.46 \mathrm{a}$ & $0.19 \mathrm{a}$ \\
\hline & & A & $15.61 \mathrm{c}$ & $7.45 \mathrm{~b}$ & $2.81 \mathrm{~b}$ & $0.22 \mathrm{a}$ \\
\hline
\end{tabular}

'Cultivars: BC = 'Blue Cupido', FC = 'Favorite Cupido', SC = Scarlet Cupido, and SU = 'Sunrise Cupido’.

yHormone treatments: $\mathrm{N}=$ no hormone, $\mathrm{H}=$ hormone.

Inoculation treatments: $\mathrm{C}=$ no inoculum, $\mathrm{W}=$ washings from arbuscular mycorrhizal fungus $(\mathrm{AMF}) \mathrm{inoculum}, \mathrm{A}=\mathrm{AMF}$ inoculum.

wMeans followed by the same letter within a cultivar and variable are not significantly different from each other $(P<0.05$, Bonferroni test). 
Table 2. Influence of hormone and inoculation treatments on root composition of four miniature rose cultivars $14 \mathrm{~d}$ after sticking.

\begin{tabular}{|c|c|c|c|c|c|c|}
\hline \multirow[b]{2}{*}{ Variable } & \multirow{2}{*}{$\begin{array}{l}\text { Hormone } \\
\text { treatment }\end{array}$} & \multirow{2}{*}{$\begin{array}{l}\text { Inoculation } \\
\text { treatment }^{x}\end{array}$} & \multicolumn{4}{|c|}{ Cultivar ${ }^{z}$} \\
\hline & & & $\mathrm{FC}$ & $\mathrm{SC}$ & SU & $\mathrm{BC}$ \\
\hline Protein & $\mathrm{N}$ & $\mathrm{C}$ & $8.67 \mathrm{a}^{\mathrm{w}}$ & $5.38 \mathrm{a}$ & $0.32 \mathrm{a}$ & $0.15 \mathrm{a}$ \\
\hline content & & W & $13.61 \mathrm{ab}$ & $6.61 \mathrm{a}$ & $0.76 \mathrm{a}$ & $0.66 \mathrm{a}$ \\
\hline \multirow[t]{4}{*}{ ( $\mu \mathrm{g} /$ cutting) } & & A & $29.67 \mathrm{~b}$ & $11.53 \mathrm{a}$ & $7.35 \mathrm{~b}$ & $0.24 \mathrm{a}$ \\
\hline & $\mathrm{H}$ & $\mathrm{C}$ & $27.39 \mathrm{~b}$ & $19.35 \mathrm{a}$ & $1.53 \mathrm{a}$ & $1.15 \mathrm{a}$ \\
\hline & & W & $50.90 \mathrm{c}$ & $44.94 \mathrm{~b}$ & $5.39 \mathrm{ab}$ & $1.41 \mathrm{a}$ \\
\hline & & $\mathrm{A}$ & $81.31 \mathrm{~d}$ & $54.15 \mathrm{~b}$ & $26.87 \mathrm{c}$ & $2.48 \mathrm{~b}$ \\
\hline \multirow{6}{*}{$\begin{array}{l}\text { Amino acid } \\
\text { content } \\
(\mu \mathrm{g} / \text { cutting })\end{array}$} & $\mathrm{N}$ & $\mathrm{C}$ & $138.0 \mathrm{a}$ & $75.84 \mathrm{a}$ & $82.0 \mathrm{a}$ & $3.48 \mathrm{a}$ \\
\hline & & W & $301.2 \mathrm{ab}$ & $218.3 \mathrm{ab}$ & $239.1 \mathrm{a}$ & $7.44 \mathrm{a}$ \\
\hline & & A & $783.1 \mathrm{c}$ & $433.5 \mathrm{c}$ & $1606.2 \mathrm{~b}$ & $5.62 \mathrm{a}$ \\
\hline & $\mathrm{H}$ & $\mathrm{C}$ & $258.1 \mathrm{a}$ & $270.0 \mathrm{~b}$ & $443.0 \mathrm{a}$ & $5.54 \mathrm{a}$ \\
\hline & & $\mathrm{W}$ & $478.9 \mathrm{~b}$ & $427.1 \mathrm{c}$ & $312.7 \mathrm{a}$ & $5.34 \mathrm{a}$ \\
\hline & & A & $1187.9 \mathrm{~d}$ & $605.2 \mathrm{~d}$ & $6657.8 \mathrm{~b}$ & $16.98 \mathrm{~b}$ \\
\hline \multirow{6}{*}{$\begin{array}{l}\text { Reducing sugar } \\
\text { content } \\
(\mu \mathrm{g} / \text { cutting })\end{array}$} & $\mathrm{N}$ & $\mathrm{C}$ & $20.06 \mathrm{a}$ & $17.53 \mathrm{a}$ & $6.53 \mathrm{a}$ & $2.45 \mathrm{a}$ \\
\hline & & W & $57.28 \mathrm{ab}$ & $57.63 \mathrm{a}$ & $17.18 \mathrm{a}$ & $3.79 \mathrm{a}$ \\
\hline & & A & $131.29 \mathrm{~b}$ & $150.50 \mathrm{~b}$ & $194.49 \mathrm{~b}$ & $6.24 \mathrm{a}$ \\
\hline & $\mathrm{H}$ & $\mathrm{C}$ & $128.65 \mathrm{~b}$ & $144.96 \mathrm{~b}$ & $65.71 \mathrm{ab}$ & $3.14 \mathrm{a}$ \\
\hline & & W & $243.62 \mathrm{c}$ & $295.67 \mathrm{c}$ & $115.41 \mathrm{ab}$ & $4.16 \mathrm{a}$ \\
\hline & & A & $653.58 \mathrm{~d}$ & $400.46 \mathrm{~d}$ & $822.55 \mathrm{c}$ & $24.52 \mathrm{~b}$ \\
\hline \multirow{6}{*}{$\begin{array}{l}\text { Nonreducing sugar } \\
\text { content } \\
(\mu \mathrm{g} / \text { cutting })\end{array}$} & $\mathrm{N}$ & $\mathrm{C}$ & $2.60 \mathrm{a}$ & $1.66 \mathrm{a}$ & $0.82 \mathrm{a}$ & $0.53 \mathrm{a}$ \\
\hline & & W & $4.81 \mathrm{ab}$ & $5.47 \mathrm{a}$ & $3.46 \mathrm{a}$ & $0.76 \mathrm{a}$ \\
\hline & & A & $10.95 \mathrm{~cd}$ & $14.29 \mathrm{~b}$ & $35.31 \mathrm{~b}$ & $0.59 \mathrm{a}$ \\
\hline & $\mathrm{H}$ & $\mathrm{C}$ & $8.44 \mathrm{bc}$ & $2.91 \mathrm{a}$ & $5.53 \mathrm{a}$ & $0.75 \mathrm{a}$ \\
\hline & & W & $14.76 \mathrm{~d}$ & $18.88 \mathrm{bc}$ & $13.94 \mathrm{a}$ & $1.99 \mathrm{a}$ \\
\hline & & A & $38.49 \mathrm{e}$ & $22.83 \mathrm{c}$ & $90.61 \mathrm{c}$ & $1.64 \mathrm{a}$ \\
\hline
\end{tabular}

zCultivars: BC = 'Blue Cupido', FC = 'Favorite Cupido', SC = Scarlet Cupido, and SU = 'Sunrise Cupido'.

yHormone treatments: $\mathrm{N}=$ no hormone, $\mathrm{H}=$ hormone.

xInoculation treatments: $\mathrm{C}=$ no inoculum, $\mathrm{W}=$ washings from arbuscular mycorrhizal fungus (AMF) inoculum, $\mathrm{A}=\mathrm{AMF}$ inoculum.

${ }^{w}$ Means followed by the same letter within a cultivar and variable are not significantly different from each other $(P<0.05$, Bonferroni test).

inoculated with AMF washings ( $\approx 26 \%)$. Similarly, hormone treatments had a higher proportion of total reducing sugars content in roots $(\approx 36 \%)$ than nonhormone treatments $(\approx 12 \%)$. Nonreducing sugar content of roots accounted for $<7 \%$ of the total nonreducing sugar content of cuttings and neither hormone treatment nor inoculation with AMF significantly altered allocation of nonreducing sugars between stems and roots (data not shown).

RELATIONSHIP BETWEEN STEM METABOLITES AND ROOT PRODUCTION. Stem protein concentrations at $0 \mathrm{~d}$ were positively correlated with root biomass (Spearman $\mathrm{R}=0.487 ; P<0.05$ ) at $14 \mathrm{~d}$, while stem amino acid concentrations at $0 \mathrm{~d}$ were positively correlated with root biomass (Spearman $\mathrm{R}=0.665 ; P<0.05$ ) and root number (Spearman $\mathrm{R}=0.504 ; P<0.05$ ) at $14 \mathrm{~d}$. Reducing sugar concentrations in stems at $0 \mathrm{~d}$, however, were not significantly correlated with root production, and nonreducing sugar concentrations were negatively correlated with root biomass (Spearman $\mathrm{R}=-0.57 ; P<0.05$ ) at $14 \mathrm{~d}$. Changes in nonreducing sugars were dependant on cultivar and not specifically related to rooting (data not shown).

\section{Discussion}

AMF inoculation increased adventitious root production in miniature rose cultivars before any colonization was detected (especially when hormone was applied); indicating that signaling existed between the plant stem and AMF propagules. Precolonization signaling between plants and AMF has been reported (Gadkaret al., 2001; Giovannetti et al., 1996). A sequence of signaling/recognition events may occur during different stages of plant-AMF interactions, but little is known about these signaling molecules (Roussel et al., 2001). These molecules have been investigated in root-AMF interactions, but not in interactions between stems and AMF. Stem-AMF signaling may not be as specific as the interactions that occur between roots and AMF. The plant's role in the interaction may be a release of metabolites or $\mathrm{CO}_{2}$ from the end of the cutting. This release, similar to the process of root exudation, causes a general stimulus that may activate the fungal spores and/or hyphae (Tamasloukht et al., 2003). The fungus may induce plant metabolic changes through the release of fungal metabolites (Larose et al., 2002), thereby increasing rooting on cuttings inoculated with AMF.

Studies on woody plant species show AMF's ability to alter plant growth prior to root colonization. Scagel (2000) used the same fungal isolate used herein on different cultivars of miniature rose, and found that the rooting response is detectable prior to colonization. Douds et al. (1995) also reported that AMF influenced plant growth and development before roots were colonized in Sciadopitys verticillata cuttings. AMF inoculation significantly increased survival, callus development, and rooting percentages in the cuttings, which usually take up to 6 months to root. Linderman and Call (1977) reported that AMF enhanced rooting of a non-AMF plant, Arctostaphylos uva-ursi (L.) Spreng.

Verkade and Hamilton (1981) found that substantial increases in root development coincided with extensive mycorrhizal devel- 
opment on roots of Ligustrum obtusifolium Siebold \& Zucc. var. regelianum (Koehne) Rehder after 6 weeks of rooting. However, no effects on root initiation were found. In a later study, Verkade and Hamilton (1987) found that the presence of AMF increased root development and growth of Viburnum dentatum L., but again found no effect on root initiation. Although it appeared that inoculation of $V$. dentatum cuttings increased root initials at 5 weeks, they concluded that this increase occurred only after infection, and was mediated through the effect of the fungus on plant metabolism rather than the effect of fungal exudates prior to infection. Increases in root initiation and growth of miniature rose are not always associated with increased levels of AMF colonization (Scagel, 2001). Also, specific levels of AMF inoculum may to be required for optimal rooting response as described for hick's yew (Taxus ×media Rehder 'Hicksii') (Scagel et al., 2003).

Differences in plant response to AMF inoculum could also be attributed to microorganisms associated with the inoculum (Linderman, 1988). For example, in cuttings of 'Favorite Cupido' and 'Scarlet Cupido' that were inoculated with AMF washings and treated with hormone, root biomass was significantly greater than that of noninoculated cuttings (Table 1). Scagel (2001) reported that the percentage of rooted miniature rose cuttings was similar when cuttings were treated with either AMF or washings from the inoculum, but root initiation was higher in cuttings treated with AMF than those treated with only washings. The relationship between plant growth promoting rhizobacteria (PGPR) and AMF has been documented (Barea et al., 1976; Meyer and Linderman, 1986). Parladé et al. (1999) noted that fumigated substrate decreased rooting in douglas-fir [Pseudotsuga menziesii (Mirb.) Franco] cuttings. Others have reported that AMF recognition responses to host-derived signals occur in sterile conditions (Giovanetti et al., 1996). This implies that the plant-fungus signaling that leads to the rooting responses in the AMF treatments may be separate from interactions between the cutting stem and the organisms in the inoculum washings.

Cultivar-specific responses to AMF inoculum, such as degree and type of rooting, varied among the four cultivars. Cultivarspecific responses to AMF have been documented for several factors, including nutrition and fungal-plant recognition (Clark and Zeto, 2000; Graham and Eissenstat, 1994; Koide, 1991). Scagel (2001) reported cultivar-specific responses to AMF during the propagation of miniature rose cuttings. At 4 weeks, cultivarspecific differences in root initiation (i.e., number of primary roots) in response to AMF inoculation were detected (Scagel, 2001). Some cultivars rooted better with AMF inoculum regardless of hormone treatment, while other AMF treatments required hormone for better rooting. The combination of rooting hormone and AMF inoculum generally resulted in a higher percentage of rooted cuttings with a higher number of roots than cuttings in hormone treatments without AMF. The cultivar-specific responses with miniature roses reported in Scagel (2001) and in the current study may be due to the following: 1) the relationship between inoculum level and rooting response (Scagel et al., 2003); 2) specific interactions between cultivars, AMF, and associated bacteria in the inoculum; and 3) traits specific to each cultivar, such as environmental, nutritional, or hormonal requirements for optimal rooting.

Moisture retention during adventitious rooting is important for cutting survival (Hartmann et al., 1997). Hormone and AMF treatments resulted in increased moisture retention in the present study. Inoculated cuttings of hick's yew have also been reported to be more hydrated than noninoculated cuttings; plants inoculated with AMF had higher root weight, suggesting that root initiation and growth increased levels of tissue hydration (Scagel et al., 2003). Lower hydration levels observed in inoculated cuttings during the first few days of the experiment may be due to decreased callus induction (e.g., 'Scarlet Cupido', Fig. 1C). Mycorrhizal fungi may alter root exudation patterns, allowing for increased metabolite flow from roots during the first stages of AMF-root interaction (Buee et al., 2000; Larose et al., 2002). This interaction may also cause a decrease in callus production on cutting stems. Since hormone application did not cause a similar moisture loss or lack of callus formation, this response in inoculated cuttings may not be related to hormonally mediated mechanisms in root formation.

Root size can affect several aspects of root function. We found that root size (mg/root) was generally increased (fatter or longer roots) by treatment with hormones or by inoculation with AMF for all cultivars but 'Blue Cupido' (Table 1). Similar results for roots on miniature rose cuttings treated with hormone were reported by Scagel (2001). In the same study, cuttings from miniature rose cultivars with $G$. intraradices inoculum in the rooting substrate had similar root size when compared to cuttings from untreated controls $28 \mathrm{~d}$ after sticking. The differences in root size responses to AMF inoculation reported this study with the results presented here may be a result of the different length of the studies. When AMF were added to the rooting media of hick's yew cuttings, roots of inoculated cuttings were similar in size to untreated controls $108 \mathrm{~d}$ after cuttings were stuck, however, $156 \mathrm{~d}$ after cuttings were stuck, roots on inoculated cuttings were significantly smaller than roots on untreated controls (Scagel et al., 2003). Since root length and diameter were not measured in any of these studies, it is impossible to state whether the smaller roots were shorter or thinner or whether larger roots were fatter or longer. This alteration in root size and anatomy on cuttings appears to be time dependant and may influence the function of the new root system relative to water and nutrient uptake, as well as survival during transplanting. Further study is needed to determine how root size and anatomy on hormone-treated cuttings differ from roots on cuttings from rooting media containing AMF inoculum and on untreated controls. A detailed study on the anatomical differences between these roots could aid in determining the mechanism through which AMF inoculum increases root initiation and growth in cuttings.

The concentrations and contents of metabolic reserves in cuttings have been related to rooting ability (Druege et al., 2000; Haissig, 1984; Henry et al., 1992). In chrysanthemum [Dendranthema $\times$ grandiflorum (Ramat.) Kitamura], the number and length of adventitious roots formed on cuttings were positively correlated with initial nitrogen content of the cuttings. However, prerooting concentrations of carbohydrates in cuttings did not limit rooting. Increased rooting was associated with higher sucrose:starch ratios in cuttings, reflecting an increased assimilate export needed for rooting (Druge et al., 2000). With miniature roses we also found that nitrogen containing compounds appear to play a primary role in adventitious root formation while initial carbohydrate concentrations may play a smaller, yet interactive, role. In fact, one cultivar we tested, 'Blue Cupido', had protein concentrations equal to other cultivars and very low amino acid concentrations. This cultivar produced the least number of adventitious roots even though cuttings contained high concentrations of reducing sugars.

Inoculation of plants with AMF has been shown to increase the concentrations of specific proteins and amino acids in roots 
(Hause et al., 2002; Krishna and Bagyaraj, 1983). Mycorrhizal colonization can also increase carbon sink strength in roots of plants resulting in larger concentrations of reducing sugars in roots (Wright et al., 1998). Our work with miniature rose cuttings shows that plant metabolic changes in protein concentrations and content showed responses to both AMF and hormone application and were detectable within 7 to $14 \mathrm{~d}$ after cuttings were stuck. Cuttings that were treated with hormones or inoculated with AMF generally produced and/or accumulated more proteins, amino acids, and carbohydrates in roots compared to cuttings that received no hormones or inoculum. Although many reports describe changes in plant composition during colonization by AMF, few studies have reported changes in stem and root composition prior to colonization. Our results suggest a sequence of signaling/recognition events may occur during different stages of plant-AMF interactions during rooting. This implies that signaling molecules may be responsible for this interaction (Roussel et al., 2001) and that signal compounds released from the AMF may induce plant metabolic changes (Larose et al., 2002) and vice versa. In our study the qualitative characteristics of proteins, amino acids, and reducing sugars were not determined, however, our results imply that not only are there AMF/root signaling events but there may also be more general $\mathrm{AMF}$-plant interactions that are expressed even though roots are not present on cuttings.

\section{Conclusions}

Many changes in metabolism are known to occur during adventitious root formation including changes in amino acids and proteins important for enzyme function and nitrogen metabolism, and changes in carbohydrates (see Davis and Haissig, 1994). With miniature roses nitrogen containing compounds appear to play a primary role in adventitious root formation and differences in protein and amino acids between cuttings exposed to inoculum and cuttings with no inoculum were detectable within s 7 to $14 \mathrm{~d}$ after cuttings are stuck. Carbohydrate concentrations appear to play a less important role in formation of adventitious roots, but may play a role in regulating part of the $\mathrm{AMF}$-plant interaction involved in AMF-induced increasing in adventitious root formation. This ability of mycorrhizal fungi to alter cutting metabolism offers researchers a useful tool to better understand the physiology occurring during adventitious root formation.

\section{Literature Cited}

Barea, J.M., E. Navarro, and E. Montoya. 1976. Production of plant growth regulators by rhizosphere phosphate-solubilizing bacteria. J. Appl. Bacteriol. 40:129-134.

Biermann, B.J. and R.G. Linderman. 1980. Quantifying vesicular-arbuscular mycorrhizae: A proposed method towards standardization. New Phytol. 87:63-67.

Bradford, M. 1976. A rapid and sensitive method for the quantification of microgram quantities of protein utilizing the principle of protein dye binding. Anal. Biochem. 72:248.

Buee, M., M. Rossignol, A. Jauneau, R. Ranjeva, and G. Becard. 2000. The pre-symbiotic growth of arbuscular mycorrhizal fungi is induced by a branching factor partially purified from plant root exudates. Mol. Plant-Microbe Interactions 13:696-698.

Chang, D.C. 1994. What is the potential for management of vesicular-arbuscular mycorrhizae in horticulture?, p. 187-190. In: A.D. Robson, L.K. Abbot, and N. Malajczuk (eds.). Management of mycorrhizas in agriculture, horticulture and forestry. Kluwer Academic Publishers, Dordrecht, Netherlands.
Clark, R.B. and S.K. Zeto. 2000. Mineral acquisition by arbuscular mycorrhizal plants. J. Plant Nutr. 23:867-902.

Davis, T.D. and B.E. Haissig. 1994. Biology of adventitious root formation. Plenum Press, New York.

Dische, Z. 1962. Color reactions based on the reducing properties of sugars, p. 512-514. In: R.L. Whistler and M.L. Wolfron (eds.). Methods of carbohydrate chemistry, Vol. 1. Academic, New York.

Douds, D.D., G. Bécard, P.E. Pfeffer, L.W. Doner, T.J. Dymant, and W.M. Kayer. 1995. Effect of vesicular-arbuscular mycorrhizal fungi on rooting of Sciadopitys verticillata Sieb \& Zucc. Cuttings. HortScience 30:133-134.

Druege, U., S. Zerche, R. Kadner, and M. Ernst. 2000. Relation between nitrogen status, carbohydrate distribution and subsequent rooting of chrysanthemum cuttings as affected by pre-harvest nitrogen supply and cold-storage. Ann. Bot. 85:687-701.

Gadkar, V., R. David-Schwartz, T. Kunik, and Y. Kapulnik. 2001. Arbuscular mycorrhizal fungal colonization. Factors involved in host recognition. Plant Physiol. 127:1493-1499.

Gibbons, J.D. 1985. Nonparametric statistical inference. 2nd ed. Marcel Dekker, New York.

Giovannetti, M., C. Sbrana, A.S. Citernesi, and L. Avio. 1996. Analysis of factors involved in fungal recognition reponses to host-derived signals by arbuscular mycorrhizal fungi. New Phytol. 133:65-71.

Graham, J.H. and D.M. Eissenstat. 1994. Host genotype and the formation and function of VA mycorrhizae, p. 179-185. In: A.D. Robson, L.K. Abbot, and N. Malajczuk (eds.). Management of mycorrhizas in agriculture, horticulture and forestry. Kluwer Academic Publishers, Dordrecht, Netherlands.

Haissig, B.E. 1984. Carbohydrate accumulation and partitioning in Pinus banksiana seedlings and seedling cuttings. Physiol. Plant. 61:13-19.

Hartmann, H.T., D.E. Kester, F.T. Davies, and R.L. Geneve. 1997. Plant propagation: Principles and practices. 6th ed. Prentice-Hall, Upper Saddle River, N.J.

Hause, B., W. Maier, O. Miersch, R. Kramell, and D. Strack. 2002. Induction of jasmonate biosynthesis in arbuscular mycorrhizal barley roots. Plant Physiol. 130:1213-1220.

Henry, P.H., F.A. Blazich, and L.E. Henesley. 1992. Nitrogen nutrition of containerized eastern red cedar. II. Influence of stock plant fertility on adventitious rooting of stem cuttings. J. Amer. Soc. Hort. Sci. 117:568-570

Koide, R.T. 1991. Nutrient supply, nutrient demand and plant response to mycorrhizal fungal infection. New Phytol. 117:365-386.

Krishna, K.R. and D.J. Bagyaraj. 1983. Changes in the free amino nitrogen and protein factions of groundnut caused by inoculation with VA mycorrhizal. Ann. Bot 51:399-401.

Larose, G., R. Chenevert, P. Moutoglis, S. Gagne, Y. Piché, and H. Vierheilig. 2002. Flavonoid levels in roots of Medicago sativa are modulated by the developmental stage of the symbiosis and the root colonizing arbuscular mycorrhizal fungus. J. Plant Physiol. 159:1329-1339.

Linderman, R.G. 1988. Mycorrhizal interactions with rhizosphere microflora: The mycorrhizosphere effect. Phytopathology 78:366-371.

Linderman, R.G. and C.A. Call. 1977. Enhanced rooting of woody plant cuttings by mycorrhizal fungi. J. Amer. Soc. Hort. Sci. 102:629632.

Meyer, J.R. and R.G. Linderman. 1986. Response of subterranean clover to dual inoculation with vesicular-arbuscular mycorrhizal fungi and a plant growth-promoting bacterium, Pseudomonas putida. Soil Biol. Biochem. 18:185-190.

Nelson, N. 1944. A photometric adaptation of the Somogyi method for determination of glucose. J. Biol. Chem. 153:375.

Nemec, S. 1987. VA Mycorrhizae in horticultural systems, p. 193-212. In: G.R. Safir (ed.). Ecophysiology of VA mycorrhizal plants. CRC Press, Boca Raton, Fla.

Parladé, J., J. Pera, I.F. Alvarez, D. Bouchard, B. Genere, and F. Tacon. 1999. Effect of inoculation and substrate disinfection method on rooting and ectomycorrhiza formation of Douglas fir cuttings. Ann. For. Sci. 56:35-40. 
Phillips, J.M. and D.S. Hayman. 1970. Improved procedures for clearing roots and staining parasitic and vesicular-arbuscular mycorrhizal fungi for rapid assessment of infection. Trans. Br. Mycol. Soc. 55:158-161.

Roussel, H., D. van Tuinen, P. Franken, S. Gianinazii, and V. GianinazziPearson. 2001. Signaling between arbuscular mycorrhizal fungi and plants: Identification of a gene expressed during early interactions by differential RNA display analysis. Plant Soil 232:13-19.

Scagel, C.F. 2000. Using mycorrhizal fungi during propagation of woody horticultural crops. Comb. Proc. Intl. Plant Prop. Soc. 50:589-594.

Scagel, C.F. 2001. Cultivar specific effects of mycorrhizal fungi on the rooting of miniature rose cuttings. J. Environ. Hort.:15-20.

Scagel, C.F., K. Reddy, and J.M. Armstrong. 2003. Mycorrhizal fungi in rooting substrate influences the quantity and quality of roots on stem cuttings of hick's yew. HortTechnology 13:62-66.

Smith, S.E. and D.J. Read. 1997. Mycorrhizal symbiosis. 2nd ed. Academic, San Diego, Calif.

Tamasloukht, M.B., N. Séjalon-Delmas, A. Kluever, A. Jaunean,
C. Roux, G. Bécard, and P. Franken. 2003. Root factors induce mitochondrial-related gene expression and fungal respiration during the developmental switch from asymbiosis to presymbiosis in the arbuscular mycorrhizal fungus Gigaspora rosea. Plant Physiol. $131: 1468-1478$

Verkade, S.D. and D.F. Hamilton. 1981. Mycorrhizae and their use in the nursery. Comb. Proc. Intl. Plant Prop. Soc. 30:353-362.

Verkade, S.D. and D.F. Hamilton. 1987. Effect of endomycorrhizal inoculum on root initiation and development of Viburnum dentatum L. cuttings. J. Environ. Hort. 5:80-81.

Woomer, P.L. 1994. Most probable number counts, p. 59-79. In: R.W. Weaver (ed.). Methods of soil analysis, part 2. Soil Sci. Soc. Amer., Madison, Wis.

Wright, D.P., D.J. Read, and J.D. Scholes. 1998. Mycorrhizal sink strength influences whole plant carbon balance of Trifolium repens L.. Plant Cell Environ. 21:881-891.

Yemm, E.W. and E.C. Cocking. 1955. The determination of amino acids with ninhydrin. Analyst. 80:209-213. 